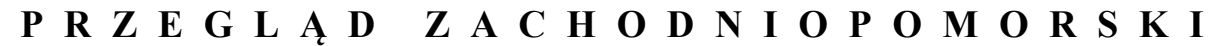 ROCZNIK XXXIV (LXIII) ROK 2019 ZESZYT 3
}

\section{$\begin{array}{lllllllll}\mathbf{A} & \mathbf{R} & \mathbf{T} & \mathbf{Y} & \mathbf{K} & \mathbf{U} & \mathbf{L} & \mathbf{Y}\end{array}$}

\author{
AgNIESZKA BoRYSOWSKA \\ ORCID: 0000-0003-3638-4248 \\ Książnica Pomorska w Szczecinie \\ e-mail: a.borysowska@ksiaznica.szczecin.pl
}

\section{EILHARD LUBINUS (1565-1621) I MUZA RZYMSKA ${ }^{1}$}

Słowa kluczowe: Eilhard Lubinus; satyra rzymska - recepcja; łacińska twórczość okolicznościowa; poezja nowołacińska; Akademia Rostocka

Keywords: Eilhard Lubinus; Roman satire - reception; Latin occasional literature; Modern Latin poetry; Rostock Academy

Eilhard Lubinus, najbardziej znany jako twórca wielkiej mapy Pomorza (Nova Illustrissimi Ducatus Pomeraniae Tabula, Amsterdam 1618) i współcześnie określany najczęściej mianem kartografa ${ }^{2}$, był przez całe zawodowe życie nauczycielem akademickim, związanym z jedną uczelnią - Akademią Rostocką ${ }^{3}$. Zwyczajem swoich czasów wykształcenie zdobył, wędrując przez liczne ośrodki akademickie, w jego przypadku - siedziby znakomitych uniwersytetów protestanckich:

1 Przyjęłam określenie spopularyzowane przez Zygmunta Kubiaka, który Muza rzymska nazwał opracowaną przez siebie antologię poezji rzymskiej - pod terminem tym w niniejszym artykule kryć się będzie zarówno antyczna poezja rzymska, jak i twórczość poetycka samego Lubinusa, nawiązująca do starożytnych wzorców poprzez język i klasyczne metra.

2 Tej sferze działalności uczonego została ostatnio w całości poświęcona obszerna publikacja Eilharda Lubinusa podróż przez Pomorze, red. R. Skrycki, Szczecin 2013.

3 Kariera akademicka Lubinusa zob. Lubinus, Eilhard, w: Catalogus Professorum Rostochiensium, http://cpr.uni-rostock.de/resolve/id/cpr_person_00001356?_search=fdd8c95a-3fbe-4a3a-b57e-c9ec5eld65b5 (dostęp 9.08.2018); pozostałe szczegóły biografii za: Lubinus, Eilhard (Eilert Lübben), w: Deutsche Biographie, https://www.deutsche-biographie.de/ sfz54517.html (dostęp 9.08.2018). 
począwszy od Lipska, przez Kolonię, Helmstedt, Strasburg, Jenę, Marburg, aż po Rostock. Zwieńczeniem edukacji było magisterium ze sztuki zdobyte na uniwersytecie w Rostocku pod kierunkiem Nathana Chytraeusa (1543-1598), wykładającego w tej wszechnicy poezję. Nathan Chytraeus był filologiem, dramatopisarzem i poetą uwieńczonym (poeta laureatus), jednym z najlepszych piór swoich czasów, prywatnie zaś - młodszym bratem słynnego teologa Davida Chytraeusa (1530-1600), który także przez kilkadziesiąt lat pracował na rostockiej uczelni (1561-1600).

Naukowe zainteresowanie poezją rzymską ujawnił Lubinus już jako świeżo upieczony magister, kiedy opracował i wydał (w 1595 r.) zbiór komentarzy do Satyr Persjusza, którego poezja uchodziła za tak niejasną i zawikłaną, że owa obscuritas (niejasność ${ }^{4}$ ) czy też aenigmata Persiana (Persjuszowe zagadki) stały się przysłowiowe5. Nawiązanie do trudności, jakich przysparza dzieło Persjusza, pojawiło się także w tytule opracowania Lubinusa: In Auli Persi poetarum doctissimi, obscurissimi Satyras paraphrasis. Książka, jak powiedziano, stanowiła obszerny komentarz filologiczny i interpretację sześciu utworów, składających się na dorobek satyryczny antycznego twórcy, nie zawierała natomiast tekstów poetyckich. Została wydana w Amsterdamie, a dedykowana Ulrykowi i Davidowi Chytraeusom, synom Davida Chytraeusa. Jak możemy się dowiedzieć z podtytułu i treści dedykacji, opracowanie miało służyć edukacji szkolnej, toteż młodzi Chytraeusowie byli stosownymi adresatami takiego dzieła, a jednocześnie można przypuszczać, że wybór ten był ukłonem Lubinusa wobec Davida Chytraeusa seniora, który - w przeciwieństwie do młodszego brata - do końca życia cieszył się niezachwianą pozycją w Akademii Rostockiej. Warto bowiem nadmienić, że promotor Lubinusa, Nathan Chytraeus, wplątany w kontrowersje teologiczne i oskarżany o tzw. kryptokalwinizm, musiał opuścić Rostock w 1593 roku, uwalniając zajmowaną przez niemal 30 lat katedrę poetyki. Być może więc właśnie praca poświęcona Persjuszowi utorowała Lubinusowi drogę do stanowiska wykładowcy poezji w Rostocku, które otrzymał w roku jej wydania (1595).

Badania Lubinusa nad poezją rzymską, które początkowo wynikały zapewne wyłącznie z zainteresowań naukowych, w kolejnych latach były już więc powiązane z zadaniami powierzonymi mu na uczelni. Jako profesor poetyki, wzorem

${ }^{4} \mathrm{O}$ ile nie zaznaczono inaczej, wszystkie tłumaczenia $\mathrm{z}$ łaciny pochodzą od autorki.

5 Zob. Persius, w: Mała encyklopedia kultury antycznej, red. Z. Piszczek, Warszawa 1990, s. 585 . 
innych nauczycieli akademickich i gimnazjalnych, opracowywał pomoce naukowe dla swoich słuchaczy. Do dzieła Persjusza powrócił w 1598 roku, kiedy opublikował w miejscowej oficynie edycję satyr ${ }^{6}$, i ponownie w 1602 roku - wówczas ukazał się opracowany na nowo komentarz, co zostało zasygnalizowane w zmienionym tytule dzieła: In Auli Persii Satyrarum librum Ecphrasis nova, succincta et perspicua qua Poeta obscurissimus dilucide explicatur (Rostochii 1602).

Równolegle do prac nad dorobkiem poetyckim Persjusza rozwijał Lubinus inne zainteresowania filologiczne związane z poezją antyczną - zresztą nie tylko rzymską, ale i grecką - w wyniku czego powstawały kolejne opracowania i wydawnictwa. W 1597 roku opublikował w Rostocku własnym nakładem komentarz do pierwszej księgi ód Horacego ${ }^{7}$. W kolejnym roku wydał komentarze do pozostałych ksiąg pieśni ${ }^{8}$ i do księgi epod ${ }^{9}$. W 1599 roku komentarze do wszystkich ksiąg ód oraz do Carmen saeculare zostały przedrukowane we wspólnym tomie ${ }^{10}$. W tym samym roku ukazało się także omówienie pozostałych dzieł Horacego Sermones i Epistulae, w tym Ars poetica ${ }^{11}$. Opracowania poświęcone poezji Horacego nie zawierały edycji utworów, składały się wyłącznie z komentarza filologicznego. Wszystkie te publikacje, poza pierwszą (omawiającą pieśni z pierwszej księgi), ukazały się w oficynie rostockiego drukarza Christopha Reusnera. Musiały być chętnie wykorzystywane przez czytelników, skoro drukarz zdecydował

${ }^{6}$ Auli Persii Flacci Satyrae VI accuratissime emendatae et editae ab Eilhardo Lubino, Rostochii 1598.

7 Eilhardi Lubini in Q. Horatii Flacci poemata omnia paraphraseon scholiasticarum specimen, sive liber primus. Quo primus Odarum liber retentis poetae verbis, et prosae insertis commentarii vice breviter et dilucide explicatur, Rostochii 1597.

8 Zob. E[ilhardi] Lubini in Q. Horatii Flacci odarum librum II. paraphrasis scholastica qua retentis et insertis poetae verbis auctor commentarii vice mira luce et brevitate plene explicatur, Rostochii 1598; Eilhardi Lubini in Q. Horatii Flacci carminum vel odarum librum III paraphrasis scholastica nova in qua retentis poetae verbis iisque pedestri sermoni insertis auctor hic gravissimus plene explicatur, Rostochii 1598; Eilhardi Lubini in Q. Horatii Flacci carminum vel odarum librum IIII paraphrasis scholastica nova in qua retentis poetae verbis iisque pedestri sermoni insertis auctor hic gravissimus plene explicatur, Rostochii 1598.

9 Zob. Eilhardi Lubini in Q. Horatii Flacci odarum librum ultimum qui epodon inscribitur paraphrasis scholastica nova in qua retentis poetae verbis iisque pedestri sermoni insertis auctor hic gravissimus plene explicatur, Rostochii 1598.

${ }^{10}$ Eilhardi Lubini in Q. Horatii Flacci poemata quae exstant omnia paraphrasis scholastica qua retentis poetae verbis et pedestri sermoni insertis auctor gravissimus et difficillimus pleni commentarii vice breviter et dilucide explicatur, Rostochii 1599.

${ }^{11}$ Eilhardi Lubini in Q. Horatii Flacci duos Satyrarum, totidem Epistolarum et Epistolam Satyricam De Arte Poetica libros paraphrasis scholastica nova quae pleni commentarii vice esse poterit, Rostochii 1599. 
się na wznowienie tych prac. W 1613 roku opublikował w jednym tomie wszystkie komentarze opracowane przez Lubinusa, a dodatkowo znalazły się w nim także teksty poezji Horacego. Rok wcześniej pełne wydanie ${ }^{12}$ dzieł Horacego wraz z komentarzami uczonego ukazało się we Frankfurcie nad Menem.

W tych samych latach, w których pracował nad poezją Horacego, zajął się Lubinus twórczością jeszcze jednego antycznego poety rzymskiego - Juwenalisa. W 1599 roku wydał tekst jego Satyr ${ }^{13}$, a w 1602 roku - komentarze ${ }^{14}$ do nich. Rok później poezje Juwenalisa i Lubinusowy komentarz ukazały się we wspólnym tomie $\mathrm{e}^{15}$.

Wybór poetów rzymskich, których dorobkowi poświęcił Lubinus swoją uwagę badawczą, nie wydaje się przypadkowy. Wszyscy trzej: Horacy, Juwenalis i Persjusz, byli satyrykami; satyra jako gatunek poetycki była zresztą wynalazkiem rzymskim. Wiersze tworzone w tym gatunku odnosiły się do otaczającego świata, obnażały ludzkie słabości i głupotę, piętnowały upadek obyczajów. Wprawdzie Lubinus wziął na swój filologiczny warsztat cały dorobek poetycki Horacego, nie tylko jego Sermones, nie ulega jednak wątpliwości, że i tego poetę cenił przede wszystkim za twórczość satyryczną. Pisze o tym w kilkustronicowym tekście zatytułowanym Eilhardi Lubini pro Iuvenale apologeticus, dołączonym do edycji Satyr Juwenalisa:

Inter omnes utriusque linguae auctores, quorum monumenta praeteritorum seculorum barbariei erepta et ab interitu vindicata ad nos usque pervenerunt: nulli mihi unquam potiores visi illis, qui inter tam profligatos omnibus mundi temporibus mores omne suum scribendi studium et conatum ad vitam et mores corrigendos contulerunt, contemptisque opibus et honoribus multis potius prodesse, quam placere maluerunt. Quo in scribendi genere apud priscos Romanos nomen suum cumprimis profitebantur, magistri virtutum et censores morum Satyrici, qui praeclaro

${ }^{12}$ Quinctus Horatius Flaccus accuratissime emendatus, \& explicatus Paraphrasi Nova Scholiastica Eilhardi Lubini iam de integro edita, \& multis in locis correcta, Francofurti 1612.

${ }^{13}$ Iunii Iuvenalis Aquinatis Satyrarum libri quinque: post omnium editionem... emendati \& editi ab Eilhardo Lvbino poeseos in Academia Rostochchina professore publico, Rostock 1599.

${ }^{14}$ Eilhardi Lubini in D. Iunii Iuvenalis Satyrarum libros ecphrasis succinta et perspicua, Rostochii 1602.

${ }^{15}$ D. Iunii Iuvenalis Satyrarum Libri V: ex duobus manuscriptis exemplaribus ... cum analysi \& doctissimis commentariis, partim nunc primum, partim de integro editis Eilhardi Lubini, Hanoviae 1603. 
in mortales studio atque merito, misso illo, quod ad aes exit et plerique sectantur studio communia privatis praeferentes vulgi ac potentiorum odio vel amore spreto, ut cum illorum uno loquar: „Uni aequi virtuti, atque eius amici”'16.

[Pośród wszystkich tworzących w obydwu językach, których świadectwa barbarzyństwa dawnych wieków, zachowane i uratowane od zniszczenia, doszły aż do nas, żadni nie wydawali mi się nigdy lepsi od tych, którzy wobec tak wielkiego upadku zasad we wszystkich epokach ludzkości całą swoją gorliwość i wysiłek pisania skierowali na poprawę życia i obyczajów - odrzuciwszy bogactwa i liczne godności, chcieli raczej pomagać niż się podobać. W tym to sposobie pisania wśród starożytnych Rzymian sławne imię swoje objawili przede wszystkim Satyrycy nauczyciele cnót i strażnicy obyczajów - którzy z godną podziwu gorliwością i dobrodziejstwem na rzecz śmiertelnych, porzuciwszy to, co trwa po spiżu, w istocie w większości z zapałem wciąż tropią, przedkładając wspólne dobro nad korzyści osobiste, po tym jak wzgardzili wprzód nienawiścią albo miłością motłochu i możnych, że wraz z jednym z nich rzeknę: ,„Jednej cnocie równi i jej przyjaciele”].

Warto w tej wypowiedzi zwrócić uwagę nie tylko na treści, które zostały wyrażone explicite, ale i na to, co autor przekazał w sposób aluzyjny, z pewnością jednak czytelny dla wykształconego odbiorcy. W istocie wartościuje on tu twórczość poetycką i na przykładzie Horacego ukazuje, co w tego typu pracy jest najistotniejsze. Nie jest to bynajmniej urok liryki - a przecież właśnie miano najwspanialszego liryka wszechczasów zyskał Horacy! Świadomość własnego geniuszu i siły poetyckiego czynu kazała mu z dumą wyrzec w epilogu trójksięgu pieśni słynną frazę ,exegi monumentum aere perennius ${ }^{17}$ - wybudowałem pomnik trwalszy niż ze spiżu”, która pobrzmiewa także w przytoczonym zdaniu Lubinusowego apologetyku (,misso illo, quod ad aes exit - porzuciwszy to, co trwa po spiżu”). Lubinus tymczasem ceni poetów za wyzbycie się tego typu ambicji. Każe im baczyć nie na wieczną sławę, lecz na pożytki płynące z ich poezji dla śmiertelników. Owa pokonująca bariery czasu sława, tak zresztą jak chwilowe uznanie, były stałymi motywami podejmowanymi przez poetów i częstymi elementami rozważań teoretyków poezji. Pisał o tym także Horacy, nie tylko widząc w poezji narzędzie zyskania nieśmiertelności za pośrednictwem jej wiecznotrwałych pomników, ale przestrzegając również przed pokusą taniej

${ }^{16}$ Tamże, s. 1.

${ }^{17}$ Horacy Carm. III, 30, 1, tłum. A. Ważyk, wszystkie fragmenty pieśni i ich przekłady za wydaniem: Kwintus Horacjusz Flakkus, Dzieła wszystkie. T. 1, Ody i epody, Warszawa 2000. 
popularności i poklasku thumu. „Odi profanum vulgus et arceo ${ }^{18}$ - Pogardzam tłumem i nie znam go zgoła" - zadeklarowany przez Wenuzyjczyka dystans do tłumu, także powraca w przytoczonej wyżej wypowiedzi Lubinusa (,vulgi ac potentiorum odio vel amore spreto - po tym jak wzgardzili wprzód nienawiścią albo miłością motłochu i możnych”). Satyryk bowiem nie może oglądać się ani na niechęć, ani na poklask, który może wzbudzić swoją muzą, chłoszczącą przywary współczesnych. Dotyczy to zresztą nie tylko stosunku poety do małych, ale i do wielkich tego świata. Rozwija Lubinus tę myśl, puentując swoją wypowiedź (po raz trzeci!) parafrazą słów Horacego ${ }^{19}$ - tym razem pochodzących z Satyry II, 1, tej samej, w której antyczny poeta wymawia się przed opiewaniem „dzieł niezwyciężonego Cezara za wielką nagrodę” (,aude Caesris invicti res dicere, multa laborum praemia laturus ${ }^{20 "}$ ). Wyimek z tego wiersza, który przytacza Lubinus, opisujący satyryków jako „przyjaciół cnoty”, wskazuje więc jednocześnie na jedyny jego zdaniem godny pochwały cel poezji, jak i na jedyne warte uznania wartości z niej płynące - dydaktyzm - wskazywanie drogi wiodącej ku właściwym wartościom. Innymi słowy, poeta, uprawiając poezję, powinien się kierować li tylko podpowiedzią cnoty, sięgający zaś po tomik poezji czytelnik tego właśnie w niej szukać. Nie trzeba dodawać, że tak nakreślona rola poezji pasowała do poglądów wykładowcy protestanckiej uczelni. To wszak reformacyjny model kształcenia na każdym etapie wskazywał na konieczność łączenia przekazywanej wiedzy z właściwą formacją duchową - właściwą, to jest zgodną $\mathrm{z}$ doktryną ukształtowaną przez Lutra.

Lubinus, który cenił satyrę najwyżej ze wszystkich gatunków poetyckich, sam również pokusił się w różnych okresach życia o stworzenie wierszy tego typu. Najwcześniejszym drukowanym utworem tego rodzaju jest opublikowany w 1596 roku łaciński wiersz w heksametrze, zatytułowany De resurectione mortuorum. Utwór osnuty wokół kwestii odkupienia win i sądu ostatecznego rozpoczyna się słowami (w. 1-4):

Quod Satyrarum auctor de priscae moribus urbis

omne in praecipiti vitium stet it, inquit, idipsum

Verius et melius de nostri moribus aevi

dixeris.

${ }^{18}$ Horacy Carm. III, 1, 1, thum. T.F. Hahn.

${ }^{19}$ Horacy Serm. II, 1, 70: „scilicet uni aequos virtuti atque eius amicis”.

${ }^{20}$ Horacy Serm. II, 1, 10-11. 
[Wszystko, co autor satyr odnośnie do obyczajów starożytnego miasta kładł na karb upadku, to samo, rzecze, prawdziwiej i lepiej o obyczajach naszego wieku mógłbyś powiedzieć].

To wyraźne nawiązanie genologiczne i tematyczne uwypuklone zostało także w tytule całego druczku: Declamatio Satyrica in huius saeculi impietatem, qua resurrectio mortuorum futura invictis rationibus et argumentis demonstra$t u r^{21}$. Wiersz został napisany w związku z objęciem katedry poetyki w Akademii Rostockiej w 1595 roku, o czym Lubinus informuje w dedykacji dzieła. Okolicznościowy charakter utworu uwidacznia się także w końcówce, w której Lubinus powierza szkołę i jej wychowanków opiece Boga.

Okazjonalny charakter miał także tomik Eilhardi Lubini in huius saeculi male doctos, Academiarum pestes, et malitiam impune grassantem, declamationes satyricae tres, publice diversis temporibus in Academia Rostochiensi recitatae (Rostochii 1618). Całość zbioru została przypisana księciu pomorskiemu Ulrykowi, z którym Lubinus znał się osobiście jeszcze z czasów, gdy nastoletni książę był honorowym rektorem akademii w Rostocku (1602-1603). Właśnie w 1603 roku swój pierwszy rektorat na Akademii sprawował i Lubinus. Z lektury dedykacji wynika, że tomik został wydany już po śmierci księcia Filipa II, innego władcy ze szczecińskiej linii Gryfitów, którego filolog z Rostocku znał osobiście i z którym w ostatnich latach jego życia miał serdeczne kontakty, gdyż to właśnie z inicjatywy tego władcy opracowywał słynną mapę Pomorza.

Zgodnie z tym, co podpowiada tytuł, w tomiku znalazły się trzy utwory napisane na potrzeby uroczystości szkolnych. Pierwszą z nich była ceremonia promowania nowych magistrów filozofii, która odbyła się 4 czerwca 1602 roku. Utwór ten był już wcześniej publikowany samodzielnie ${ }^{22}$. Kolejny z wierszy (In pestas academiarum) powstał $\mathrm{w}$ związku ze sprawowaniem przez Lubinusa po raz drugi funkcji rektora w 1615 roku. Trzeci utwór natomiast został napisany w roku wydania zbioru na coroczne obchody w gmachu akademii rocznicy śmierci księcia Meklemburgii, Ulryka, które przypadały na 14 marca. Ponieważ

${ }^{21}$ Eilhardi Lubini Declamatio satyrica in huius saeculi impietatem, qua resurrectio mortuorum futura invictis rationibus et argumentis demonstratur, Rostock 1596.

${ }^{22}$ Eilhardi Lubini in nostri saeculi male doctos, satura publice recitata in Illustri Academia Rostochiensi cum novem... iuvenis... gradum in philosophia conferret, Rostochii 1603. 
miesiąc wcześniej (3 lutego) zmarł Filip II, z którym książę Ulryk był skoligacony (jego drugą żoną była księżniczka pomorska Anna, córka Filipa I), stało się to pretekstem do przypomnienia także i tego władcy. Pamięci świeżo zmarłego księcia Filipa II poświęcił Lubinus zresztą większą część swojego utworu, nawiązał w nim także do osoby imiennika księcia meklemburskiego, a brata zmarłego Filipa - księcia pomorskiego Ulryka. Wszystkie trzy wiersze zostały napisane heksametrem.

Warto nadmienić, że upamiętnionemu $\mathrm{w}$ trzeciej satyrze $\mathrm{z}$ powyższego zbioru Ulrykowi meklemburskiemu, księciu światłemu, znakomicie wykształconemu i zasłużonemu dla Akademii Rostockiej, poświęcił Lubinus także wiersz za życia. Był nim krótki poemat heksametryczny ${ }^{23}$, przedstawiający ideę dobrego władcy, napisany przez Lubinusa na początku kariery akademickiej, kiedy pełnił jeszcze obowiązki profesora poetyki, tj. w 1599 roku - na uroczysty ingres księcia Ulryka do Rostocku.

Najczęstszym jednak powodem odwoływania się przez Lubinusa do muzy poezji była śmierć opiewanej osoby. Książę szczeciński Filip II nie był jedynym Gryfitą, któremu uczony oddał po śmierci hołd wierszem. Rok wcześniej dołożył swój utwór do druku pogrzebowego ${ }^{24}$ dla młodszego brata Filipa II, Jerzego II był to długi na 78 wersów, łaciński wiersz złożony w heksametrze, zatytułowany

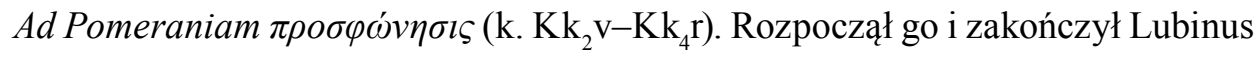
metaforą dynastii jako drzewa, od którego niespodziewanie odpadł młodziutki pęd (,postremus in arbore ramus”). W zakończeniu wyraża nadzieję na ponowne rozkrzewienie się owego pnia o nowe szczepy i zapewnia (w. 72-74):

Haec precor et dum vivo precer, nec vana precabor,

Dum saliet, laeva mihi cor sub parte mamilla

Quamquam alienigena, et quis non bonus optet idipsum!

[O to błagam i - póki żyję - błagał będę, i oby nie na darmo, jak długo bić mi będzie serce z lewej strony piersi, chociaż cudzoziemiec - lecz któż życzliwy nie życzyłby tego!]

${ }^{23}$ E. Lubinus, Illustrissimi Megapolensium Ducis, Magni Nepotis, Alberti Filii, Udalrici Reginae Daniae Patris, Regis Avi, Patris Patriae, Desideratissimus in urbem suam Rostochium ad Academiae suae visitationem ingressus, Carmen, in quo boni principis idea proponitur, Rostock 1599.

${ }^{24}$ De vita et morte... Domini Georgii III. Ducis Stetini Pomeraniae, Cassubiorum et Henetorum, Principis Rugiae... insperato attamen piissime defuncti oratio scripta et solemniter recitata ipso die exequiarum, qui est 26. Maij in Academia Illustri Gryphorum..., Stettin 1617. 
Warto zauważyć, że w owe kasandryczne tony popadł Lubinus już na okoliczność śmierci pierwszego potomka Bogusława XIII. W chwili śmierci Jerzego II żyli bowiem jeszcze jego starsi bracia: Filip (zm. 1618), Franciszek (zm. 1620) i Bogusław (zm. 1637) oraz młodszy - Ulryk (zm. 1622). Niedaleka przyszłość pokazała jednak, że obawy Lubinusa co do losów dynastii Gryfitów były słuszne.

Uczony pozostawił także inne utwory skomponowane na czas śmierci. Jednym z wcześniejszych był wiersz opublikowany $\mathrm{w}$ druku ${ }^{25}$ poświęconym upamiętnieniu m.in. Nielsa Kaasa (1535-1594), wysokiego rangą polityka, jednego z najważniejszych ludzi w państwie duńskim, od 1573 roku sprawującego urząd kanclerza, oraz Heinricha Rantzaua (1526-1598), także dyplomaty w służbie króla Danii, a przy tym wybitnego ekonoma, budowniczego, kolekcjonera i humanisty. Dwuwersowe epitafium Lubinusa znalazło się w części druku poświęconej pamięci Rantzaua:

Henrici tumulus Ranzoi hic: caetera norunt

Europae gentes, Orbis et occiduus.

[Tu oto grób Heinricha Rantzaua - resztę już poznały narody Europy i Zachodni Świat].

W 1607 roku ukazało się drukiem ${ }^{26}$ pożegnanie kolegi Lubinusa - Valentina Schachta (1540-1607), pastora kościoła św. Jakuba i długoletniego profesora teologii w Akademii Rostockiej. Druk wydany z tej okazji zawiera prozatorskie epicedium Lubinusa wygłoszone podczas uroczystości pogrzebowych, a także mowę dziekana Wydziału Teologicznego, Lucasa Bacmeistera (1570-1638), skierowaną w przeddzień ceremonii do młodzieży szkolnej. W publikacji znalazło się także krótkie wierszowane epitafium pióra Lubinusa, w którym zawarł on dość konwencjonalne wyrazy żalu w związku z odejściem Schachta - ozdoby

\footnotetext{
${ }^{25}$ Lugubres narrationes duae de obitu illustris ac generosi viri dn. Nicolai Caas... subiunctae sunt una cum programmate in Regia Hafniensium Academia publice proposito, nonnullae Elegiae funebres... Henrici Ranzovii Producis Cimbrici..., Hamburgi 1594.

${ }^{26}$ E. Lubinus, D. Valentini Schachthii Elogium parentationis vice publice recitatum in Academia Rostochiensi, Rostochii 1607.
} 
miejscowej uczelni ${ }^{27}$. Podpis pod wierszem ujawnia jednak, że relacje pomiędzy autorem a adresatem były bardzo bliskie i serdeczne:

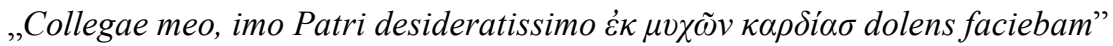

[Towarzyszowi memu, a nawet Ojcu najukochańszemu, wydobyłem, cierpiąc, $\mathrm{z}$ gębi serca].

Także inne okazje tradycyjnie uświetniane poezją skłaniały Lubinusa do takiej twórczości. Warto przywołać opublikowane w 1601 roku gratulatorium ${ }^{28}$ dla Joachima Beringa (1574-1627) z okazji magisterium z filozofii uzyskanego na Uniwersytecie Rostockim, do którego Lubinus dołożył kilka dystychów elegijnych. Bering wkrótce stał się jego kolegą po fachu - w 1604 roku objął katedrę teologii na uczelni w Greifswaldzie, a w przyszłości obronił jeszcze doktorat $\mathrm{z}$ teologii (1616). Lubinus również sprawował stanowisko profesora teologii w Rostocku od 1604 roku, doktorat z tej dziedziny uzyskał jednak nieco wcześniej niż Bering, w 1605 roku.

Kilkakrotnie natkniemy się na okolicznościowe wiersze Lubinusa także w epitalamiach, dedykowanych wstępującym w związek małżeński przyjaciołom. Jednym z nich był kolega z okresu studiów w Hamburgu Hermann Lange ${ }^{29}$ (zm. 1622), nauczyciel i pastor w tym mieście, który ożenił się w 1596 roku, innym - kolega z Rostocku, magister filozofii, Anton Aulaeus ${ }^{30}$, który wstąpił w związek małżeński w 1599 roku.

Oprócz druków okolicznościowych wiersze Lubinusa napotkamy także $\mathrm{w}$ ramie literacko-wydawniczej jego własnych i cudzych publikacji. Jednym z istotniejszych dzieł uczonego - przez wzgląd na długotrwałość oddziaływania

${ }^{27}$ Tamże, k. A 1 v: „Ille, ille, heu! nostrae Flos atque medullae Rhodanthae, | Schachtius, heu! noster Schachtius occubuit" (w. 7-8).

${ }^{28}$ Carmina gratulatoria in honorem pietate, eruditione ac virtutum laude... Viri-Iuvenis, Dn. Ioachimi Beringii... cui Magisterii Philosophici gradus, in... Academia Rostochiensi, Rostochii 1601.

${ }^{29}$ In nuptias Integerrimi, Humanissimi, Doctissimique Viri, Dn. M. Hermanni Langii Scholae Hamburgensis collegae Sponsi et Pudicissimae ac Moratissimae Virginis Annae Iegers... Sponsae carmina gratulatoria Rostochio missa ab amicis, Hamburg 1596.

${ }^{30}$ Honori nuptiali Ornatissimi et doctissimi viri, Dn. M. Antoni Aulaei, Scholae Rostochiensis Collegae Dignissimi, Sponsi, et Elyssae Dethleviae... Johannis Dethlevii filiae... gratulantur amici, Rostock 1599. 
i wywołane reperkusje $\mathrm{e}^{31}$ - była praca z pogranicza filozofii i teologii zatytułowana Phosphorus, sive De prima causa et natura mali tractatus hypermetaphysicus, in quo multorum gravissimae et dubitationes tolluntur et errores deteguntur (Rostochii 1596). Utwór został przypisany rajcom Hamburga, toteż nie dziwi, że przed tą dedykacją zamieścił Lubinus dodatkowo wiersz opiewający miasto - In laudem urbis Hamburgensi ${ }^{32}$. Jak na pochwałę przystało, kreśli w nim autor obraz ośrodka miejskiego skupiającego w sobie wszelkie zalety - mieszka w nim pobożność, piękno, sławna cnota i roztropność; jest wręcz Hamburg „ozdobą kuli ziemskiej” (,terrarum, Hamburgum, decus o”) i „najwspanialszą perłą pośród miast” („,O summarum urbium ocelle"). Tego rodzaju amplifikacja była charakterystyczna dla panegiryku, chętnie sytuowanego w obrębie dedykacji w epoce Lubinusa.

Ciekawą oprawę otrzymał zbiór poezji skomponowany przez Johannesa Melinusa $^{33}$. Tom zawiera 63 epigramaty poprzedzone anagramami ułożonymi z tytulatury władców i dostojników państwowych - takich jak wspomniani już książę meklemburski Ulryk czy Heinrich Rantzau - a także doktorów teologii, prawa, medycyny, profesorów szkół. W ramie literacko-wydawniczej znalazły się utwory dedykowane autorowi, nierzadko skomponowane w taki sam sposób jak całe dzieło Melinusa, tzn. z kombinacji anagramu i epigramatu. Wiersz dedykacyjny Lubinusa liczy 25 wersów i jest ułożony w heksametrze. Autor wyraża w nim przekonanie, że kart dzieła Melinusa, a wraz z nimi i zasług opiewanych osób, „ni śmierć, ni los, ni czas żaden nie zniszczy” (,,non mors, non fatum, non ulla aboleverit aetas"). Wiara w unieśmiertelniającą moc poezji sięga swymi korzeniami co najmniej liryki Horacego ${ }^{34}$, podobne sformułowania znajdziemy jednak także na kartach wielu dzieł nowożytnych. Warto w tym miejscu przywołać choćby foricoenium 82 Ad Petrum Myscovium Jana Kochanowskiego:

${ }^{31}$ Zob. Lubinus, Eilhard (Eilert Lübben), w: Deutsche Biographie, https://www.deutschebiographie.de/sfz54517.html (dostęp 9.08.2018): „Die langfristig wirkungsvollste Schrift aus dieser Phase ist wohl der neuplatonisch inspirierte Phosphorus, seu de natura mali (1595, 2. erw. Aufl 1601)"; współczesne omówiene zob. T. Leinkauf, Einheit und Gegensatz. Der Traktat Phosphorus sive de prima causa et natura mali des Eilhard von Lubin als Dokumet der Gegensatz-Ontologie der Spätrenaissance, w: Spätrenaissance-Philosophie in Deutschland 1570-1650, Entwürfe zwischen Humanismus und Konfessionalisierung, okkulten Traditionen und Schulmetaphysik, Red. M. Mulsow, Tübingen 2009, s. 87-120.

${ }^{32}$ Zob. E. Lubinus, Phosphorus, sive De prima causa et natura mali..., Rostochii 1596, k. $A_{1} \mathrm{v}$.

${ }^{33}$ J. Melinus, Anagrammata Principis Megapolitani, Regis Daniae, et Ducum quorundam, Doctorum, Magistrorumque Academiae Rosarum descriptionem continentia, Rostochii 1596.

${ }^{34}$ Por. Horacy Carm. II 20, 8. 
Non solum in nudis scribam mea carmina chartis,

Pectore sculpta meo sunt benefacta tua,

Quae mihi, Myscovi, nulla unquam aboleverit aetas,

Sive fruar vita, sive fruisse ferar.

[Nie tylko na czystych kartach zapiszę swe wiersze,

Twoje dobre czyny mam wyryte w sercu,

Tych mi, mój Myszkowski, żaden czas nie zniszczy,

Czy to żyć będę, czy się rozniesie, żem skonał].

Nie znaczy to, że Lubinus naśladował Kochanowskiego (choć nie można tego zupełnie wykluczyć, gdyż foricoenia ukazały się drukiem w 1584 r.), ile raczej - że stosował w swoich utworach dedykacyjnych wypracowaną jeszcze przez poetów starożytnych obiegową topikę, ukazującą doniosłą rolę poezji we wznoszeniu pomników pośmiertnej sławy. Warto nadmienić, że w swojej dedykacji nazwał adresatów dzieła Melinusa ludźmi, „których Prometeusz ulepił z lepszej gliny” (,quos e meliore Prometheus effinxit limo”). Znamienne jest, że tym samym włączył do tej kategorii także samego siebie, gdyż Melinus i jemu poświęcił anagram i epigramat w swojej książce ${ }^{35}$.

Spośród dzieł innych autorów, w których znalazła się poetycka dedykacja Lubinusa, warto jeszcze przywołać komedię autorstwa Alberta Wichgreviusa (ok. 1575-1619), rektora szkoły w Pritzwalku, zatytułowaną Cornelius relegatus sive comoedia nova (Rostochii 1600). W swoim dziele, opowiadającym losy studenta-utracjusza, zawarł Wichtgrevius realia życia akademickiego znane sobie prawdopodobnie jeszcze z czasu studiów, które podjął m.in. na Akademii Rostockiej. Na tej też uczelni sztuka została wystawiona, toteż nie dziwi, że wiersze dedykacyjne dla Wichgreviusa napisali właśnie akademicy związani z tą wszechnicą, m.in. rektor Johannes Freder (1544-1604), profesor teologii David Lobeck (1560-1603), profesor greki Johannes Posselius Młodszy (1565-1623) i Eilhard Lubinus, który pełnił wówczas obowiązki profesora poetyki.

Dla porządku warto dodać, że Lubinus chwytał za pióro i kreślił łacińskie wiersze także jako edytor poezji greckiej. Do przygotowanych przez siebie wydań

${ }^{35}$ Zob. J. Melinus, Anagrammata Principis Megapolitani..., k. $\mathrm{H}_{4} \mathrm{v}-\mathrm{H}_{5} \mathrm{v}$. 
wierszy Anakreonta ${ }^{36}$ i antologii epigramatów greckich ${ }^{37}$, dodał bowiem własne przekłady łacińskie. Jak sam jednak podkreślał, były to przekłady filologiczne - słowo do słowa - opracowane przez niego po to, by uprzystępnić czytelnikom oryginały greckie i wspomóc ich na początkowym etapie edukacji w zakresie tego języka ${ }^{38}$.

Jakkolwiek Eilhard Lubinus przez całe życie publikował łacińskie wiersze, trudno go uznać za poetę - z muzą poezji łączył go raczej flirt niż trwały związek. Dopóki pełnił obowiązki profesora poetyki, mowa wiązana była przedmiotem jego zainteresowań naukowych. To z tego okresu pochodzą edycje dzieł twórców antycznych zaopatrzone przez Lubinusa w komentarz filologiczny. Kiedy zdobył tytuł doktora teologii, zaprzestał prac nad edycjami poezji starożytnej, a z racji objęcia na uczelni katedry z tej dziedziny stał się wydawcą trójjęzycznych opracowań części Pisma Świętego i słowników grecko-łacińskich. W pracach tych kontynuował swoje zamiłowania i pasje związane z językami klasycznymi.

Jako autor utworów poetyckich działał natomiast na niwie, na której aktywni byli także inni wykształceni przedstawiciele społeczeństwa jego czasów. Była to przede wszystkim popularna ówcześnie poezja okolicznościowa, którą tworzono z racji pełnienia określonych funkcji zawodowych oraz na skutek powiązań towarzyskich. Znamiennym obyczajem było także sytuowanie wierszy w ramie literacko-wydawniczej publikacji - zarówno własnych, jak i osób, z którymi pozostawało się w jakichś związkach zażyłości. Lubinus więc - jako twórca wierszy okolicznościowych i poetyckich dedykacji - poetą raczej bywał niż był, a jego dorobek nie zdobył znaczącego miejsca w literaturze. $Z$ tego powodu w zbiorowej świadomości przetrwała przede wszystkim pamięć jego zasług na polu filologii, teologii i - nade wszystko - kartografii.

\footnotetext{
${ }^{36}$ Anacreontis lyricorum poetarum festivissimi quae restant carmina cum interpretatione Eilhardi Lubini, Rostock 1597.

${ }^{37}$ Florilegium omnium veterum graecorum poetarum epigrammatum interprete Eilhardo Lubino, [Heidelberg] 1604.

${ }^{38}$ Zob. Anacreontis lyricorum poetarum festivissimi..., k. $\mathrm{A}_{2} \mathrm{v}-\mathrm{A}_{3} \mathrm{r}$.
} 


\section{Bibliografia}

Anacreontis lyricorum poetarum festivissimi quae restant carmina cum interpretatione Eilhardi Lubini, Rostock 1597.

Auli Persii Flacci Satyrae VI accuratissime emendatae et editae ab Eilhardo Lubino, Rostochii 1598.

Carmina gratulatoria in honorem pietate, eruditione ac virtutum laude... Viri-Iuvenis, Dn. Ioachimi Beringii... cui Magisterii Philosophici gradus, in... Academia Rostochiensi, Rostochii 1601.

D. Iunii Iuvenalis Satyrarum Libri V: ex duobus manuscriptis exemplaribus ... cum analysi \& doctissimis commentariis, partim nunc primum, partim de integro editis Eilhardi Lubini, Hanoviae 1603.

De vita et morte... Domini Georgii III. Ducis Stetini Pomeraniae, Cassubiorum et Henetorum, Principis Rugiae... insperato attamen piissime defuncti oratio scripta et solemniter recitata ipso die exequiarum, qui est 26. Maij in Academia Illustri Gryphorum..., Stettin 1617.

E[ilhardi] Lubini in Q. Horatii Flacci odarum librum II. paraphrasis scholastica qua retentis et insertis poetae verbis auctor commentarii vice mira luce et brevitate plene explicatur, Rostochii 1598.

Eilharda Lubinusa podróż przez Pomorze, red. R. Skrycki, Szczecin 2013.

Eilhardi Lubini Declamatio satyrica in huius saeculi impietatem, qua resurrectio mortuorum futura invictis rationibus et argumentis demonstratur, Rostock 1596.

Eilhardi Lubini in D. Iunii Iuvenalis Satyrarum libros ecphrasis succinta et perspicua, Rostochii 1602.

Eilhardi Lubini in nostri saeculi male doctos, satura publice recitata in Illustri Academia Rostochiensi cum novem... iuvenis... gradum in philosophia conferret, Rostochii 1603.

Eilhardi Lubini in Q. Horatii Flacci carminum vel odarum librum III paraphrasis scholastica nova in qua retentis poetae verbis iisque pedestri sermoni insertis auctor hic gravissimus plene explicatur, Rostochii 1598.

Eilhardi Lubini in Q. Horatii Flacci carminum vel odarum librum IIII paraphrasis scholastica nova in qua retentis poetae verbis iisque pedestri sermoni insertis auctor hic gravissimus plene explicatur, Rostochii 1598.

Eilhardi Lubini in Q. Horatii Flacci duos Satyrarum, totidem Epistolarum et Epistolam Satyricam De Arte Poetica libros paraphrasis scholastica nova quae pleni commentarii vice esse poterit, Rostochii 1599.

Eilhardi Lubini in Q. Horatii Flacci odarum librum ultimum qui epodon inscribitur paraphrasis scholastica nova in qua retentis poetae verbis iisque pedestri sermoni insertis auctor hic gravissimus plene explicatur, Rostochii 1598. 
Eilhardi Lubini in Q. Horatii Flacci poemata quae exstant omnia paraphrasis scholastica qua retentis poetae verbis et pedestri sermoni insertis auctor gravissimus et difficillimus pleni commentarii vice breviter et dilucide explicatur, Rostochii 1599.

Eilhardi Lubini in Q. Horatii Flacci poemata omnia paraphraseon scholiasticarum specimen, sive liber primus. Quo primus Odarum liber retentis poetae verbis, et prosae insertis commentarii vice breviter et dilucide explicatur, Rostochii 1597.

Florilegium omnium veterum graecorum poetarum epigrammatum interprete Eilhardo Lubino, Honori nuptiali Ornatissimi et doctissimi viri, Dn. M. Antoni Aulaei, Scholae Rostochiensis Collegae Dignissimi, Sponsi, et Elyssae Dethleviae... Johannis Dethlevii filiae... gratulantur amici, Rostock 1599.

In nuptias Integerrimi, Humanissimi, Doctissimique Viri, Dn. M. Hermanni Langii Scholae Hamburgensis collegae Sponsi et Pudicissimae ac Moratissimae Virginis Annae Iegers... Sponsae carmina gratulatoria Rostochio missa ab amicis, Hamburg 1596.

Iunii Iuvenalis Aquinatis Satyrarum libri quinque: post omnium editionem... emendati \& editi ab Eilhardo Lvbino poeseos in Academia Rostochchina professore publico, Rostock 1599.

Kubiak Z., Muza rzymska. Poezja starożytnego Rzymu, Warszawa 1992.

Lubinus E., D. Valentini Schachthii Elogium parentationis vice publice recitatum in Academia Rostochiensi, Rostochii 1607.

Lubinus E., Illustrissimi Megapolensium Ducis, Magni Nepotis, Alberti Filii, Udalrici Reginae Daniae Patris, Regis Avi, Patris Patriae, Desideratissimus in urbem suam Rostochium ad Academiae suae visitationem ingressus, Carmen, in quo boni principis idea proponitur, Rostock 1599.

Lubinus E., Phosphorus, sive De prima causa et natura mali..., Rostochii 1596.

Lubinus, Eilhard (Eilert Lübben), w: Deutsche Biographie, https://www.deutsche-biographie.de/sfz54517.html (dostęp 9.08.2018).

Lubinus, Eilhard, w: Catalogus Professorum Rostochiensium, http://cpr.uni-rostock. $\mathrm{de} / \mathrm{resolve} / \mathrm{id} / \mathrm{cpr}$ _person_00001356?_search=fdd8c95a-3fbe-4a3a-b57e-c9ec5e1d65b5 (dostęp 9.08.2018).

Lugubres narrationes duae de obitu illustris ac generosi viri dn. Nicolai Caas... subiunctae sunt una cum programmate in Regia Hafniensium Academia publice proposito, nonnullae Elegiae funebres... Henrici Ranzovii Producis Cimbrici..., Hamburgi 1594.

Melinus J., Anagrammata Principis Megapolitani, Regis Daniae, et Ducum quorundam, Doctorum, Magistrorumque Academiae Rosarum descriptionem continentia, Rostochii 1596.

Persius, w: Mała encyklopedia kultury antycznej, red. Z. Piszczek, Warszawa 1990, s. 585 . 
Quinctus Horatius Flaccus accuratissime emendatus, \& explicatus Paraphrasi Nova Scholiastica Eilhardi Lubini iam de integro edita, \& multis in locis correcta, Francofurti 1612.

Leinkauf T., Einheit und Gegensatz. Der Traktat Phosphorus sive de prima causa et natura mali des Eilhard von Lubin als Dokumet der Gegensatz-Ontologie der Spätrenaissance, w: Spätrenaissance-Philosophie in Deutschland 1570-1650, Entwürfe zwischen Humanismus und Konfessionalisierung, okkulten Traditionen und Schulmetaphysik, red. M. Mulsow, Tübingen 2009, s. 87-120.

\section{Abstrakt}

W artykule omówiono naukowe zainteresowanie antyczną poezją rzymską, które Eilhard Lubinus ujawnił już jako świeżo upieczony magister, kiedy opracował i wydał (w 1595 r.) zbiór komentarzy do Satyr Persjusza, którego poezja uchodziła za tak niejasną i zawikłaną, że owa obscuritas (niejasność) czy też aenigmata Persiana (Persjuszowe zagadki) stały się przysłowiowe. W kolejnych latach uczony wziął na warsztat dzieła innych autorów starożytnego Rzymu - Horacego i Juwenalisa. Ten dobór nazwisk nie był przypadkowy: wszyscy trzej (Horacy, Juwenalis i Persjusz) byli satyrykami, a satyra jako gatunek poetycki była wynalazkiem rzymskim. W jednym ze swoich pism Lubinus przyznał zresztą otwarcie, że spośród wszystkich poetów antycznych ceni najwyżej właśnie satyryków - określił ich mianem „nauczycieli cnót i strażników obyczajów”. Uczony pozostawił po sobie nie tylko edycje i komentarze do rzymskiej poezji antycznej, ale próbował swoich sił także jako autor łacińskich wierszy. Jako twórca działał na niwie, na której aktywni byli także inni wykształceni przedstawiciele społeczeństwa jego czasów. Była to przede wszystkim popularna ówcześnie poezja okolicznościowa, którą tworzył z racji pełnienia określonych funkcji zawodowych oraz na skutek powiązań towarzyskich: znamy jego wiersze na pogrzeby władców i przyjaciół, na uroczystości szkolne, śluby i awanse kolegów. Znamiennym obyczajem było także sytuowanie wierszy w ramie literacko-wydawniczej publikacji - Lubinus dodawał poetyckie dedykacje zarówno do własnych książek, jak i do dzieł osób, z którymi pozostawał w jakichś związkach zażyłości. Jako autor utworów okolicznościowych i wierszowanych dedykacji Lubinus jednak poetą raczej bywał niż był, a jego dorobek poetycki nie zdobył znaczącego miejsca w literaturze. 


\title{
Lubinus AND the Roman Muse
}

\begin{abstract}
The article presents the academic interest in the Roman ancient poetry, which Eilhard Lubinus revealed when he obtained the title of Master and edited (in 1595) a collection of commentaries to the Satires written by (Aulus) Persius (Flaccus), whose poetry was considered to be so unclear and sophisticated that obsuritas or aenigmata Persiana had become proverbial. Later Lubinus analysed other authors from ancient Rome, Horace and Juvenal. That choice of names was not accidental: all the three (Horace, Juvenal and Persius) had been satirists, and satire had been invented in ancient Rome. In one place Lubinus wrote explicitly that he most highly valued satirists of all the ancient poets; and he called them 'teachers of virtues and upholders of the customs'. Lubinus left not only editions of and commentaries on the Roman ancient poetry, but he also tried his hand at writing Latin poetry. As an author he wrote what was popular at his time; it was, first of all, occasional poetry, which he wrote because of his professional functions and his position in the society; we know the poems he wrote to commemorate the funerals of rulers and his friends, school ceremonies, weddings and promotions of his colleagues, etc. It was a custom of the time to place poems in the editorial frame of publications; Lubinus added poetic dedications to his own books and to the books written by the people he was somehow related to. Yet, Lubinus wrote occasional poems and dedications only sporadically and his achievements in that area are not impressive.
\end{abstract}

